Fig. I4. Tangential section of sack wall showing stellate cell.

Fig. I5. Tracheal supply to stellate cells.

Fig. 16. Cross-section cells and corrugated intima of bulb.

Fig. I7. Cross-section cells and undulated intima of sack.

Figs. I8, I9, and 20. Saggital sections of the bulb in the regions of the connecting tube and false duct.

\title{
NOTES AND CORRECTIONS. (SYRPHIDAE, DIPTERA)
}

BY C. HOWARD CURRAN,

Orillia, Ontario.

For Chilosia rita new species, Can. Ent., Vol. LIV, page 70, read Chilosia ontario new species. Hine.

For Chilosia columbiae new species, 1. c., page 69, read Chilosia robusta

Prof. Hine's description of what is undoubtedly the same species was publisher in the March number of the Ohio Journal of Science, page $\mathrm{I}_{44}$, based on specimens from Alaska. I did not become aware of the description of this species until too late to change the name. I have also seen specimens from Washington State. The species is very close to aldrichi Hunter.

Chilosia orilliaensis occurs also in New Brunswick and I have six specimens from the vicinity of Fredericton.

Syrphus rectoides Curran may be very readily distinguished from S. genualis Williston by the fact that the latter has complete transverse black fasciae on the venter in both sexes, while the former has a median row of fuscous spots in the female and in the male these spots are more like those of $S$. ribesii $\mathrm{L}$. The female of the former may be distinguished from the female of $S$. insolitus Osburn by the narrower facial stripe which stops well before the anterinae.

Melanostoma chilosia Curran: A female specimen from Mount Ranier, Vashington, collected by Prof. A. L. Melander agrees almost perfectly with the type from Banff, Alberta, but the pile appears to be slightly longer. This species is close to $M$. (Chilosia) parva Williston, but the facial tubercle is more prominent and the legs are chiefly black, whereas in parva the legs are almost all reddish, except the bases of the femora.

Mclanostoma lata; vol. LIII, p. 276, second paragraph, line II, for "a broad crossband on the posterior half" ; read "..... on the anterior half."

\section{CHANGE OF NAMES IN CICINDELA.}

Dr. Walter Horn of Berlin informs me that two of the names recently proposed in the March number of this journal, viz: azurea and elegans, are preoccupied. This necessitates a renaming as follows :-

C. azurea is changed to $C$. wallisi.

C. elegans is changed to $C$. zestbournei.

E. E. Calder. 